\title{
The Technical Heritage of Date Palm Leaves Utilization in Traditional Handicrafts and Architecture in Egypt \& the Middle East
}

\author{
E. A. Darwish ${ }^{1, a_{\star}}$, Y. Mansour ${ }^{1, b}$, H. Elmously ${ }^{2, c}$, A. Abdelrahman ${ }^{3, d}$ \\ ${ }^{1}$ Dept. of Architecture, Ain Shams University, Egypt \\ ${ }^{2}$ Dept. of Design and Production, Ain Shams University, Egypt \\ ${ }^{3}$ Dept. of Structural Engineering, Ain Shams University, Egypt \\ a eman.atef@eng.asu.edu.eg, byasser_mansour@eng.asu.edu.eg, \\ chamed.elmously@gmail.com, damr.abdelrahman@eng.asu.edu.eg
}

Keywords: date palm leaves, technical heritage, architecture, handicrafts

\begin{abstract}
Date Palm Trees enjoy a recognized stature in Egypt since the ancient times. The abundance of Date Palm Trees and their distribution over the Nile valley, Delta, Oases and Sinai in Egypt granted them familiarity with the people that remains until the present. This familiarity is represented in the survival of various traditional techniques in the utilization of Date Palm Trees pruning residues in the fields of handicrafts and construction in rural Egypt. On the top of those pruning residues are the leaves, which rank the highest in the annual quantities. Date Palm Leaves are still widely used in traditional handicrafts and building in the poor rural areas in Egypt due their renewable availability and low cost. This paper aims to analyze the technical heritage behind those traditional utilization fields in order to identify the dominant techniques used. Those techniques, including Bundling, Rope Fastening and friction based assembly, can be introduced as the basis on which the development of those techniques for modern and contemporary uses of date palm leaves should be based in order make use of the surviving skills to sustain the familiarity needed to guarantee the success of the developed uses.
\end{abstract}

\section{Introduction}

Date palm tree acquires great importance historically, economically and socially in Egypt. The pruning residues of Date Palm are utilized in many traditional industries and construction by the cultivators and craftsmen in Egypt; thus playing a huge role in sustaining the rural societies against the immigration to urban cities, as those date palm related industries support over one million families in Egypt [1].

Date Palm Leaves, representing 52.9\% of the annual date palm pruning quantities [2], are used in various fields historically. The palm leaves were fundamental in manufacturing baskets, clothing and sandals in ancient Egypt and Nubia. The roofs were constructed by split palm trunks and leaves and the interior walls were covered by palm leaves ornaments [3]. Palm midribs and trunks have used for roofing in a fashion that still survives in Siwa Oasis [4].

Those ancient evidences prove the adaptability of date Palm leaves to our environment [5]. This high adaptability, besides flexibility and low cost, qualified the material to gain popularity and the trust of the rural craftsman in Egypt [3], which opens the door to exploit the potentials of this materials in contemporary uses as a promising fields for small projects. Those new uses ought to originate from that technical heritage in order to help those surviving skills to flourish and make use of the craftsman with that irreplaceable know-how. However, most of the previous researches have not introduced an integrated analysis of that heritage and the detailed processes of the traditional techniques that are still surviving. 


\section{Aim and Methodology}

Two of the basic elements of sustaining the industrial development of a local material are to benefit from the current craftsman skills in order to attract them to participate in the development, plus saving and expanding the base of the artisans that practice traditional techniques that can be reinforced and developed [6].

Accordingly, the industrial development of date palm leaves should be based on the traditional techniques in order to obtain a solid ground to guarantee its continuance. Therefore, the paper aims to identify the dominant traditional techniques that are most qualified to be the basis of the industrial development of date palm leaves.

This aim is fulfilled by analysis of the traditional techniques of the utilization of date palm leaves in handicrafts and construction. This analysis depends highly on the investigation of those traditional manufacturing processes in order to identify those techniques.

\section{Date Palm Leaves in Traditional Handicrafts}

Crates and Bird Cages. Nowadays, most of the date palm leaves, uses in handicrafts, specifically the midribs parts, are specialized in making crates and bird cages [3]. The manufacturing process of a bread crate is as the following as illustrated in Fig. 1:

1. The pruned date palm midribs are shaped into almost rectangular cross sections and cut to the needed specific lengths of the longitudinal and transverse members.

2. The places in the longitudinal members where the holes are to be punctured are marked. Those places are punctured by a wooden hammer.

3. The transverse members are hammered through the holes of the longitudinal members, and 2 short supporters are added on the sides of the middle longitudinal member to increase the stiffness and decrease the deformation under the load carried by the crate.

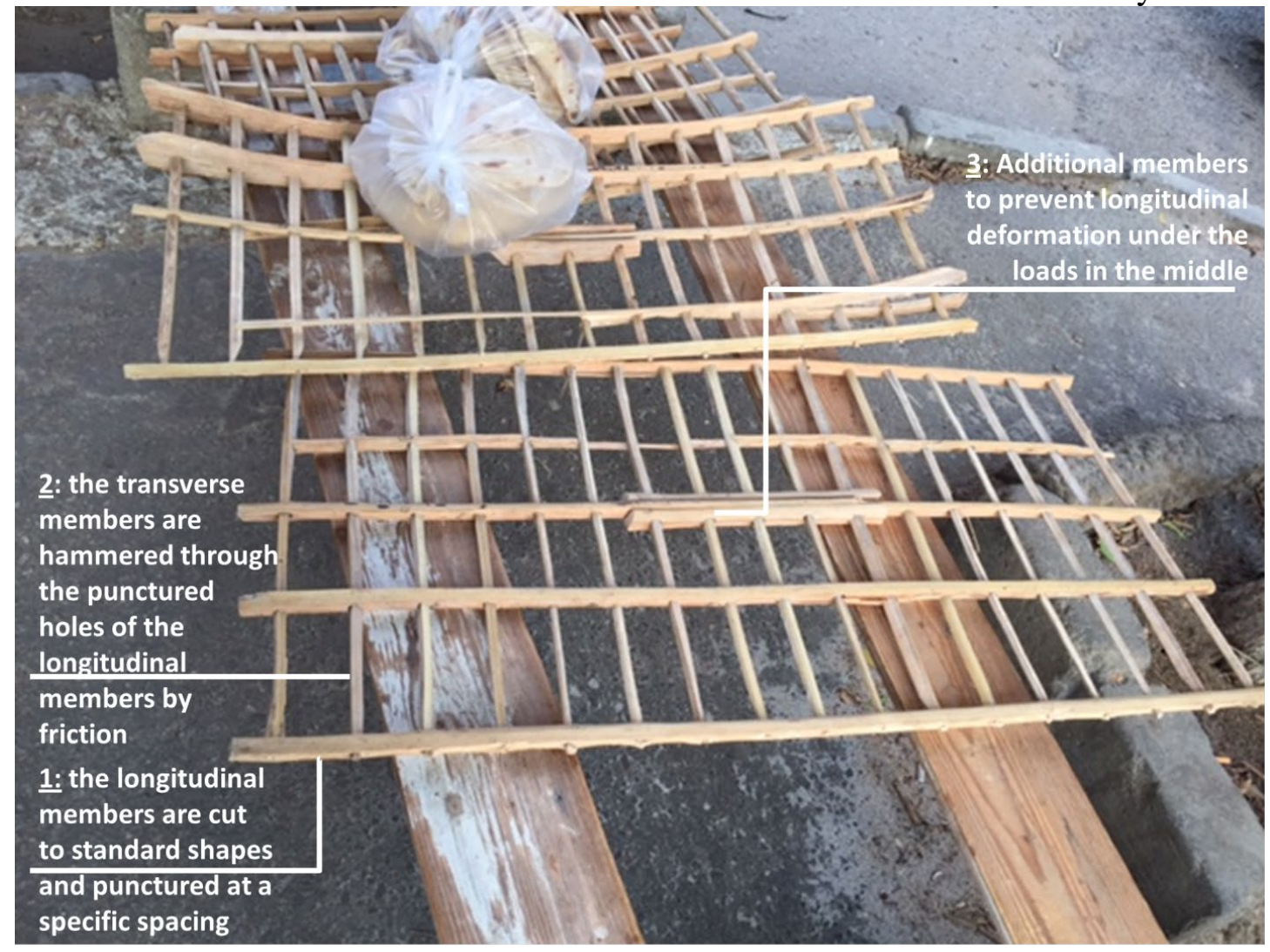

Figure 1 Bread crates made from Date Palm Midribs. 
The bird cages made from date palm midribs depend essentially on the same friction-driven fixations adopted in makes the bread crates as discussed earlier. The manufacturing process of a bird cage is as the following [3]:

1. The crate is assembled from the base up where the dowels are fixed vertically in the holes of the punctured strips until a cube is formed.

2. Additional punctured strips are laid horizontally onto the dowels to tie them together until the cube is completely latticed.

3. The top edges of the dowels are hammered to the same level.

4. Most bird cages, as illustrated in Fig. 2 , the corners of the cage are fastened with wires to make increase the overall stiffness of the cage. Another method of fastening the corners is using linen ropes around a traditional corner-block joint as illustrated in Fig. 3.

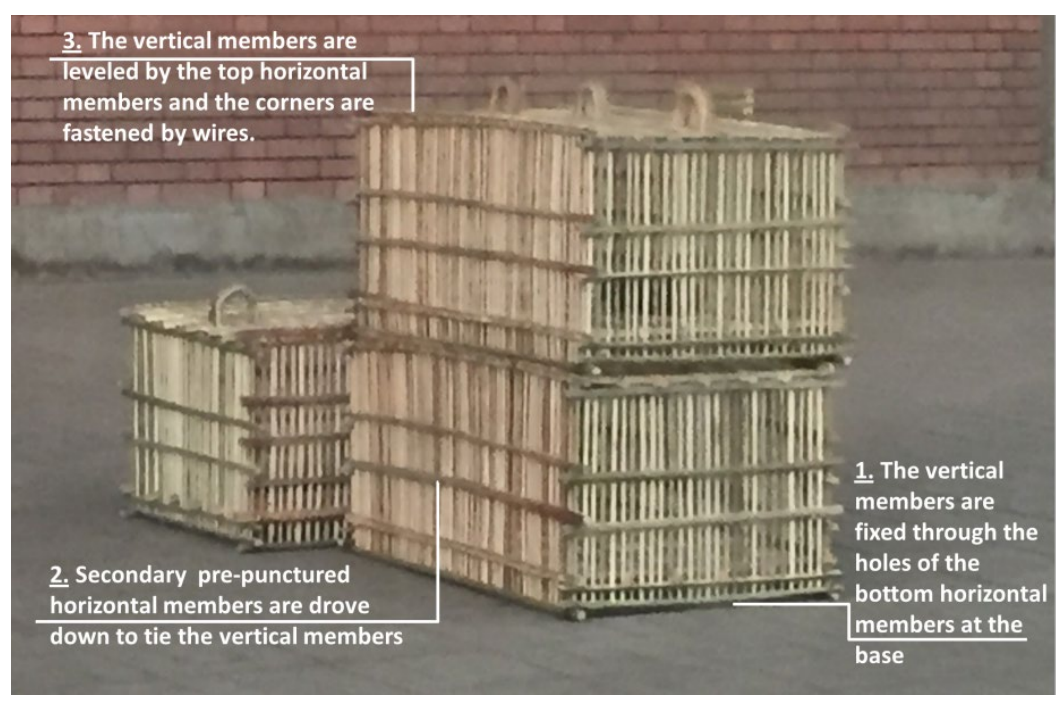

Figure 2 Bird cages made from date palm midribs

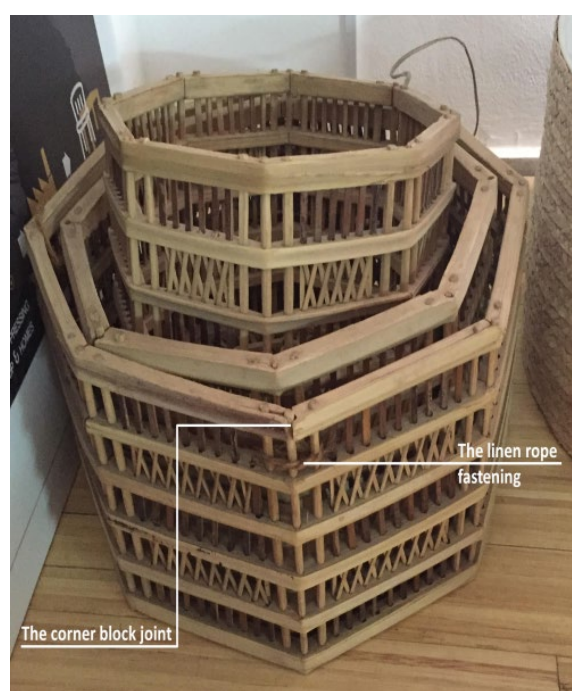

Figure 3 Cages made from date palm midribs and linen ropes

Handmade Furniture. In addition to crate making, traditional furniture items such as beds, chairs and tables are being made until the present day using date palm midribs. The manufacturing process of a chair is as the following [3]:

1. The midribs used vary from green to be easily bent to make the chair frame, and dry to be stiff enough to make the latticework. Those midribs are cut according to the needed dimensions with mostly rectangular cross sections.

2. The places where the holes are to be punctured are marked. Those places are punctured by a wooden hammer.

3. The legs of the chair are taken from the broad ends of the midribs. The seat members are cut from the straightest parts of the midribs, then the back and the armrests. Then those parts are assembled in the sequence illustrated in Fig. 2.

4. $4 \mathrm{~cm}$ - nails are used to fasten the armrests together, and $10 \mathrm{~cm}$-nails to fix them to the seat. 


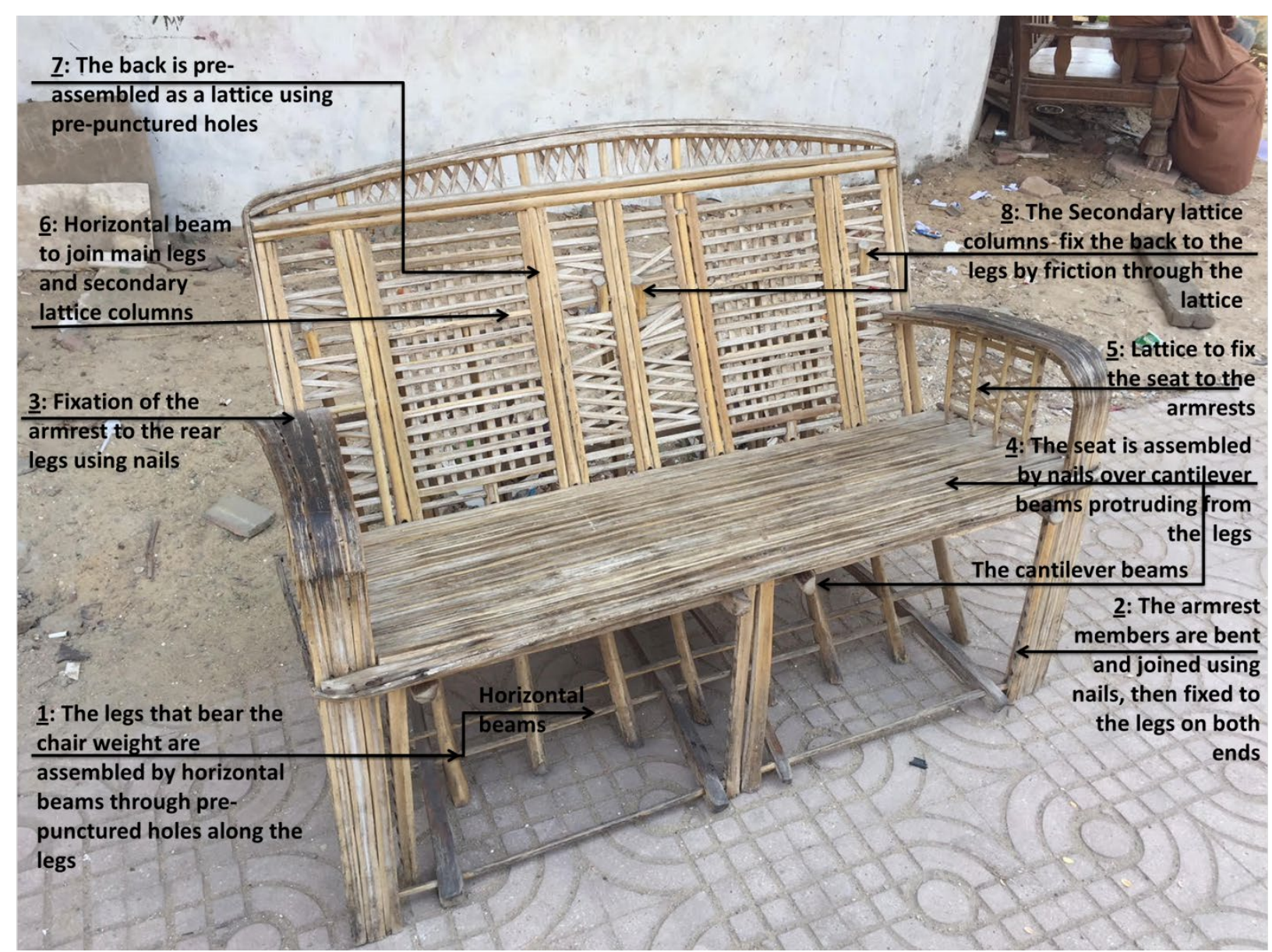

Figure 4 Chair made of Date palm midribs members

It can be realized that making furniture using date palm midribs depends on the same inherited techniques in making bird cages and crates; reforming the members, drilling and using friction in the connections while depending entirely on the natural strength of the midribs without using external reinforcement.

Leaflet Mats Hassir and Ropes. In addition, date palm leaves and midribs fibers are used in making baskets and ropes as illustrated in Fig. 5 \& Fig. 6. The manufacturing process of a mat is as the following [7]:

1. The leaves are stripped from the palm branch and laid out under the sun for two days.

2. The leaves are gathered in bunches and soaked in non-saline water for a day to facilitate bending and weaving.

3. The leaves are plaited together according to the desired shape and pattern. 


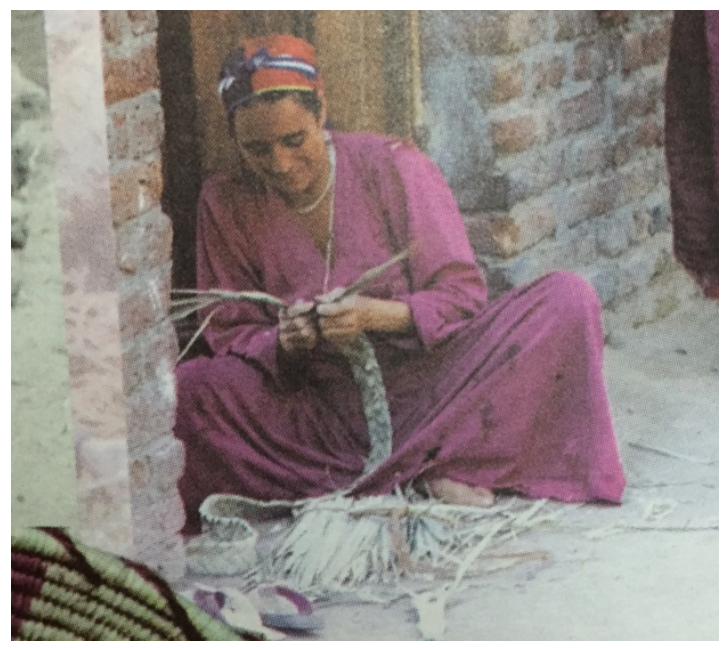

Figure 5 Date palm leaflets plaid

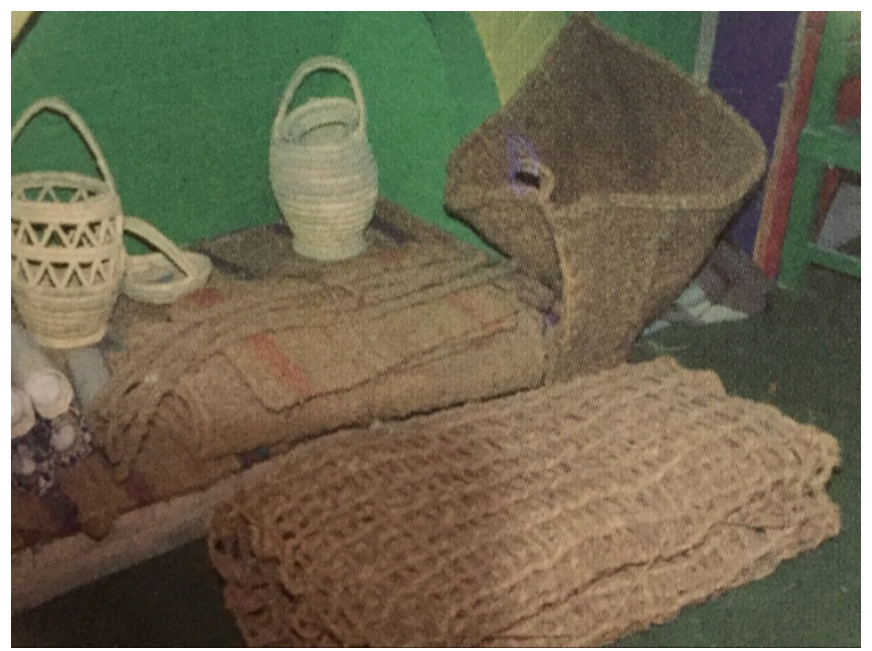

Figure 6 Nets and mats made from date palm leaflets

\section{Date Palm Leaves in Traditional Architecture}

Date palm midribs are used in many rural villages in the present day for roofing, fencing and wall sheathing after being woven into mats Sadda using sheath ropes that are extracted from date palm also in the pruning process [8].

Wickerwork Mud Layering [5]: However, the true origins of using date palm midribs in architecture go back to the ancient Egyptian rural housing in a more complicated way. Previous studies predicted that the roofs of the small houses of the workers in Ancient Egypt were made of close mats Sadda of palm midribs rows over wooden beams. The midribs were covered with a paste of mud that was so thick that it could be rain proof, and then more piles of midribs and straw were put over the mud layer as illustrated in Fig. 7 \& Fig. 8.

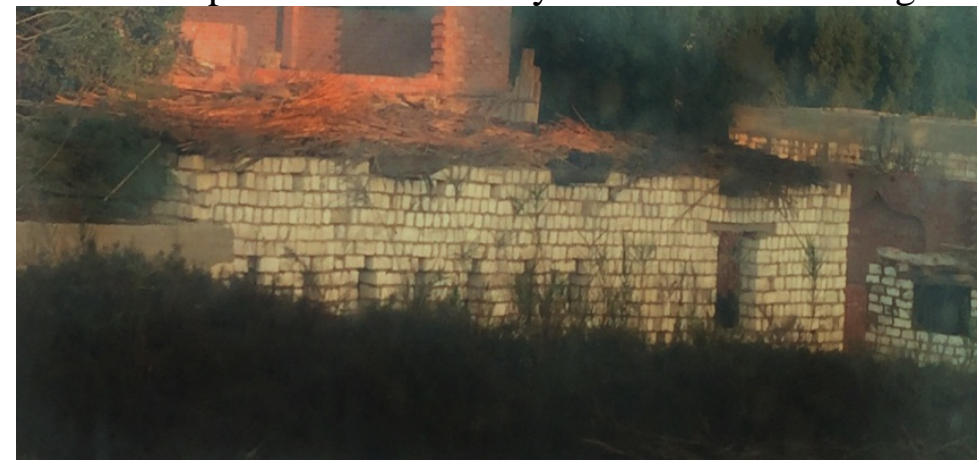

Figure 7 Piles of date palm leaves over the roof in a house in Upper Egypt

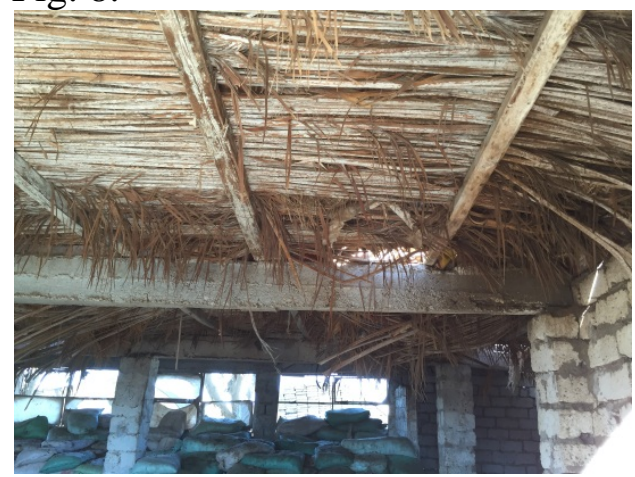

Figure 8 Date palm leaves over wooden poles for roofing in a storage house in Menya, Egypt.

Simple post-beam with palm leaves mats Sadda: On the other hand, simple huts and sheds in Egypt and UAE depend more on the skill of the tight weaving of date palm leaves, midribs and reeds for roofs and walls solely without additional mud layers [7]. The main idea of this technique is tying whole date palm leaves and reeds using ropes to a simple post-beam wooden structure system made of tree branches as illustrated in Fig. 9. 


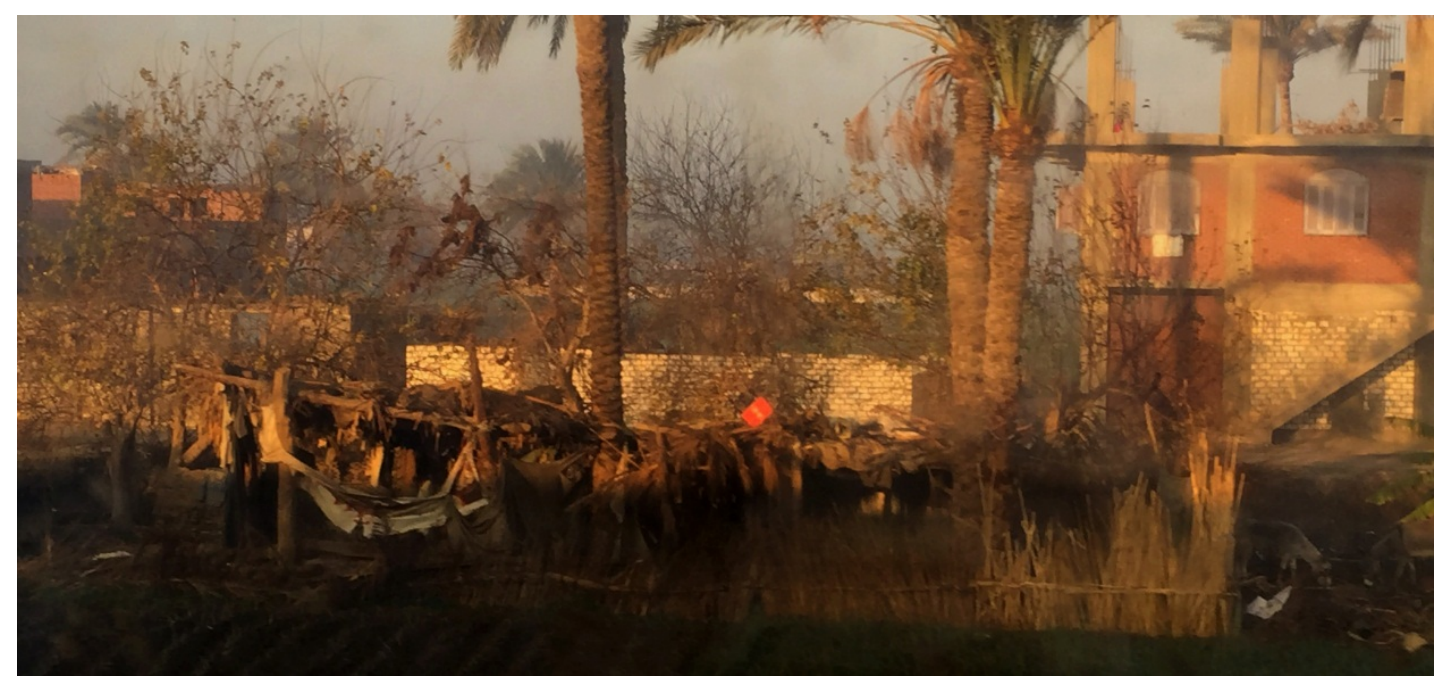

Figure 9 Date palm leaves hut in Upper Egypt

Typically, the building process is as the following [7]:

1. The dried date palm leaves are prepared by trimming the petioles and the leaves can be removed if desired.

2. The midribs are then soaked in non-saline water for a night while preparing the primary structural system using palm trunks or tree stems.

3. Making the Sadda mats by threading the ropes and the midribs. This process takes about 4 people for the walls and the roof covering.

4. Sometimes, the traditional date palm walls were built to be double layered. A double wall consists of 2 layers of midribs mats Sadda, and leaflets mats Hassir are added in the middle to provide a space for heat insulation and prevent sand from penetrating the spaces between the midribs in the wall Sadda mats.

Simple post-beam with date palm leaves bundles roofs and walls [7]: In hot arid climates such as in United Arab Emirates and in Upper Egypt, the main function of these huts is to provide a cheap shelter from direct sun, dusty winds and winter while sustaining adequate ventilation inside. This simple tying technique is more developed to be denser using weaved date palm midribs bundles as illustrated in Fig. 10 \& Fig. 11.

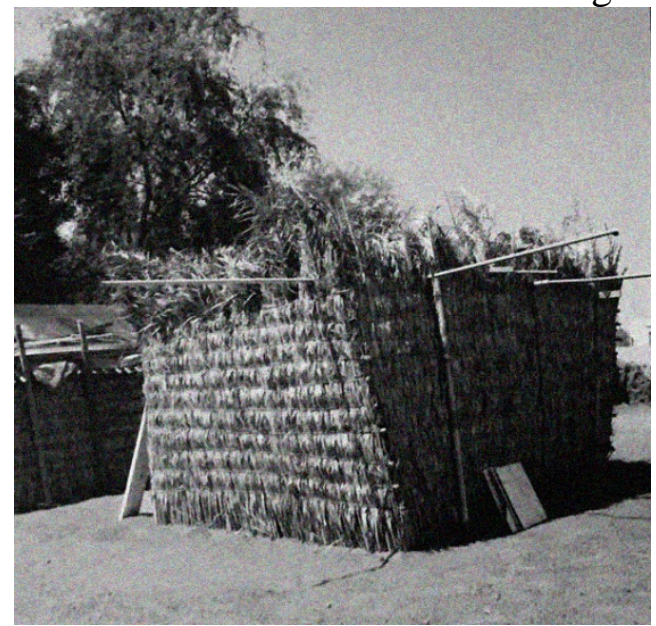

Figure 10 Date palm leaves bundles rural hut

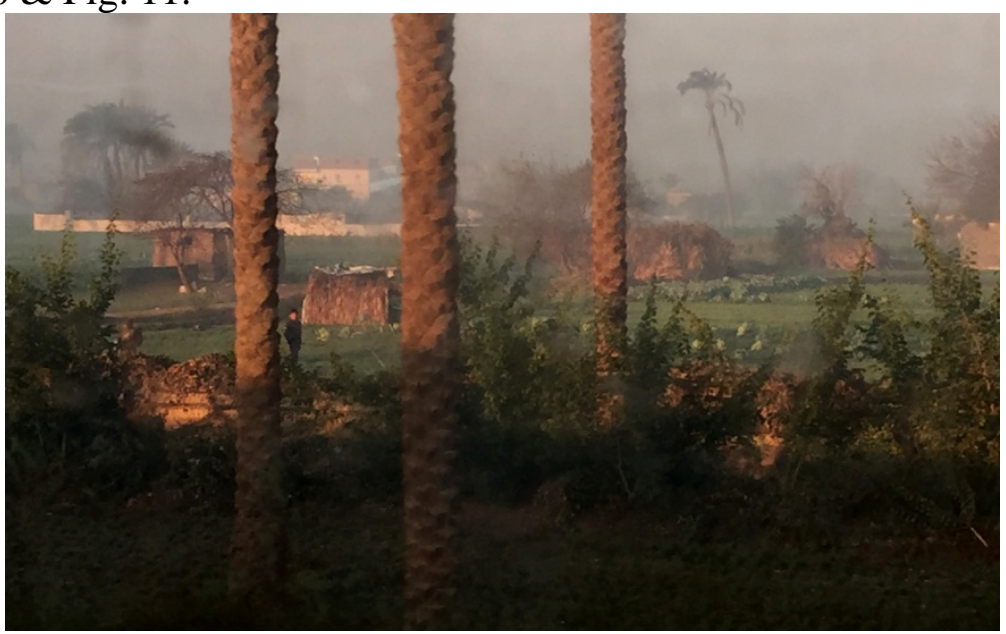

Figure 11 Dense date palm leaves huts in rural Egypt 
Fencing [9] : The simplest way of using date palm leaves in construction is in building fences. Whole date palm leaves are laid on the ground and tied together using ropes to make a single sheet that is planted in the wet soil. Then, thin date palm midribs bundles are used as horizontal beams to ensure the sheets are straight and tight as illustrated in Fig. 12.

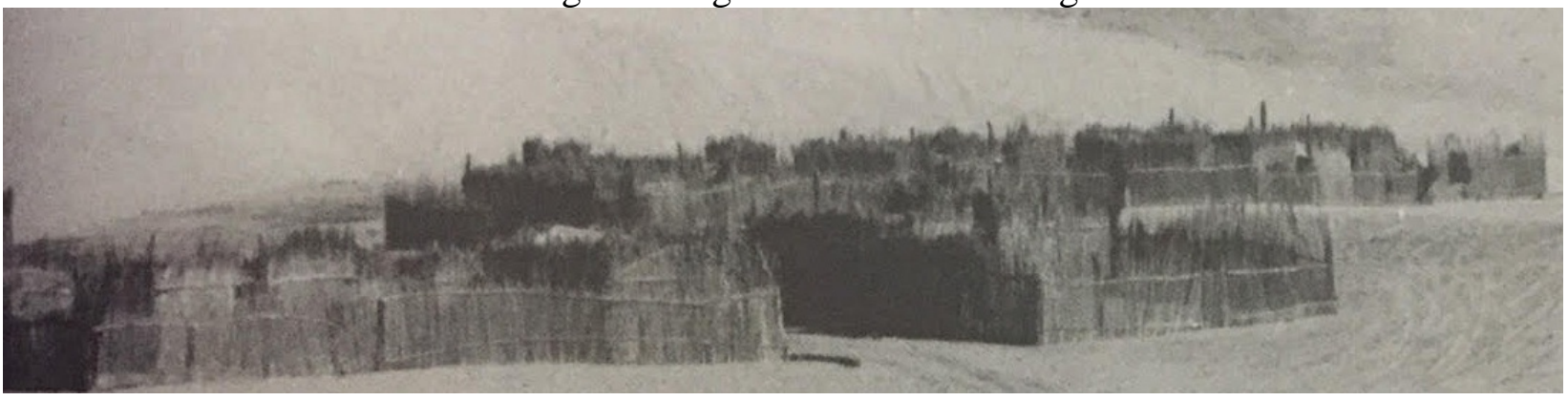

Figure 12 Date palm leaves fence in rural UAE

\section{Analysis of the technical heritage of date palm midribs}

Table 1 Summarized Analysis of the traditional techniques in handicrafts and architecture

\begin{tabular}{|c|c|c|c|}
\hline Experiment & Basic Concept & Main Techniques Used & Major Notes \\
\hline $\begin{array}{l}\text { Crates and bird } \\
\text { cages }\end{array}$ & $\begin{array}{l}\text { Lattice of transverse members } \\
\text { through holes of pre- } \\
\text { punctured longitudinal } \\
\text { members with wires/nails at } \\
\text { the corners }\end{array}$ & $\begin{array}{l}\text { Puncturing } \\
\text { Latticing } \\
\text { Friction-based assembly }\end{array}$ & $\begin{array}{l}\text { Extensively used } \\
\text { to present day }\end{array}$ \\
\hline $\begin{array}{l}\text { Handmade } \\
\text { Furniture }\end{array}$ & $\begin{array}{l}\text { Beam-joined pre-punctured } \\
\text { columns with which } \\
\text { secondary members are nailed } \\
\text { to hold the lattices }\end{array}$ & $\begin{array}{l}\text { Puncturing } \\
\text { Latticing } \\
\text { Nails Fastening } \\
\text { Friction-based assembly }\end{array}$ & $\begin{array}{l}\text { Extensively used } \\
\text { to present day }\end{array}$ \\
\hline $\begin{array}{l}\text { Leaflet Mats } \\
\text { Hassir\& Ropes }\end{array}$ & $\begin{array}{l}\text { Shredding leaves and fibers } \\
\text { threaded and weaved }\end{array}$ & $\begin{array}{l}\text { Threading } \\
\text { Weaving }\end{array}$ & $\begin{array}{l}\text { Extensively used } \\
\text { to present day }\end{array}$ \\
\hline $\begin{array}{l}\text { Wickerwork } \\
\text { Mud Layering }\end{array}$ & $\begin{array}{l}\text { Timber beams with midribs } \\
\text { mats Sadda covered with mud } \\
\text { and leaves and straw piles }\end{array}$ & $\begin{array}{l}\text { Rope Fastening } \\
\text { Mud paste }\end{array}$ & $\begin{array}{l}\text { Limited use in } \\
\text { the present day }\end{array}$ \\
\hline $\begin{array}{lr}\text { Simple } & \text { post- } \\
\text { beam } & \text { with } \\
\text { palm } & \text { leaves } \\
\text { mats Sadda }\end{array}$ & $\begin{array}{l}\text { Primary timber structure with } \\
\text { rope tied mats for roofs and } \\
\text { walls }\end{array}$ & $\begin{array}{l}\text { Rope Fastening } \\
\text { Threading } \\
\text { Weaving }\end{array}$ & $\begin{array}{l}\text { Extensively used } \\
\text { to present day in } \\
\text { temporary huts }\end{array}$ \\
\hline 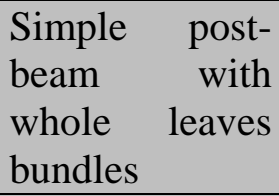 & $\begin{array}{l}\text { Primary timber structure with } \\
\text { rope stacked bundles }\end{array}$ & $\begin{array}{l}\text { Bundling } \\
\text { Rope Fastening }\end{array}$ & $\begin{array}{l}\text { Extensively used } \\
\text { to present day in } \\
\text { poor villages } \\
\text { houses and huts }\end{array}$ \\
\hline Fencing & $\begin{array}{l}\text { Vertical implanted leaves } \\
\text { mats Sadda with horizontal } \\
\text { bundled beams }\end{array}$ & $\begin{array}{l}\text { Threading } \\
\text { Weaving } \\
\text { Bundling } \\
\text { Rope Fastening }\end{array}$ & $\begin{array}{l}\text { Extensively used } \\
\text { to present day in } \\
\text { fencing around } \\
\text { cultivated lands }\end{array}$ \\
\hline
\end{tabular}

According to the analysis inTable 1, the most dominant and surviving traditional techniques are bundling, rope fastening, weaving and friction-based assembly. 


\section{Conclusion \& Recommendation}

The exploiting of the role of date palm leaves in the development of the rural communities in Egypt and the Middle East depends necessarily on their traditional techniques that originated from the people and survived in the middle of the contemporary industrialization. That surviving technical heritage is the main key by which date palm leaves uses can be modernized to match the need of the youth, while investing, and saving, the skills and the know-how that can be developed as long they still enjoy a wide base of use in the present.

This paper included analyses of the skills and techniques still used in handicrafts and construction in order to identify the most qualified for further development. The most dominant techniques that are identified from those analyses are bundling, rope fastening, weaving and friction-based assembly. It can be concluded that the techniques that are most qualified for further development are more present in the traditional huts in the poor rural areas.

This means that although most of the previous startups and small projects depending on date palm midribs are more concerned with furniture, the development of the utilization of date palm leaves and midribs in architecture is a promising field for researchers and artisans. The challenge this development needs to face is the need to produce sophisticated architecture that meets the modern lifestyle that the rural youth pursue in Egypt.

\section{References}

[1] S.A. Bekheet, S.F. El-Sharabasy, Date Palm Status and Perspective in Egypt, in Date Palm Genetic Resources and Utilization: Volume 1: Africa and the Americas, ed. by J.M. et al. Al-Khayri ([n.p]: Springer Science+Business Media Dordrecht, 1 (2015) 113. https://doi.org/10.1007/978-94-017-9694-1_3

[2] Hassan Hosseinkhani, Markus Euring and Alireza Kharazipour, Utilization of Date palm (Phoenix dactylifera L.) Pruning Residues as Raw Material for MDF Manufacturing, Journal of Materials Science Research, 4 (2015) 46-62. https://doi.org/10.5539/jmsr.v4n1p46

[3] Menha El-Batraoui, The Traditional Crafts of Egypt (Cairo: The American University in Cairo Press), 2016.

[4] R.M. Ahmed, Lessons Learnt from the Vernacular Architecture of Bedouins in Siwa Oasis, Egypt, in The 31st International Symposium on Automation and Robotics in Construction and Mining (London, UK: ISARC), 2014. https://doi.org/10.22260/isarc2014/0123

[5] Omar A. Azzam, The Development of Urban and Rural Housing in Egypt (PhD Thesis, The Swiss Federal Institute of Technology, Faculty of Technical Science), 1960.

[6] Joseph Kennedy, Building Without Borders: Sustainable Construction for the Global Village (Ontario, Canada: New Society Publishers, 2004).

[7] Sandra Piesik, Arish: Palm-Leaf Architecture, 2nd edn (London, UK: Thames \& Hudson, 2012).

[8] W. H. Barreveld, 'FAO AGRICULTURAL SERVICES BULLETIN No. 101: DATE PALM PRODUCTS ', in Food and Agriculture Organization of the United Nations $<$ http://www.fao.org/docrep/t0681e/t0681e00.htm\#con> [accessed 25 April 2018]

[9] Ayah Eldeeb, 'Recycling Agricultural Waste as a Part of Interior Design and Architectural History in Egypt', in Cities' Identity Through Architecture and Arts (Helwan: IEREK, 2017), I. 